\title{
Effect of Global Warming on Indian Agriculture
}

\author{
Ruchita Shah $^{1 *} \&$ Rohit Srivastava ${ }^{1}$ \\ ${ }^{1}$ Department of Sciences, Pandit Deendayal Petroleum University, Gujarat, India \\ ${ }^{*}$ Ruchita Shah, E-mail: ruchitapshah05@gmail.com
}

Received: November 8, 2017 Accepted: November 20, 2017 Online Published: November 22, 2017 doi:10.22158/se.v2n4p366

URL: http://dx.doi.org/10.22158/se.v2n4p366

\begin{abstract}
Agriculture is the backbone of Indian economy which in turn relies on the monsoon season. The Intergovernmental Panel on Climate Change (IPCC) projected that the global mean surface temperature will likely rise and may result into uneven climatic changes such as irregular rainfall patterns, increased surface temperature and elevated $\mathrm{CO}_{2}$ content in the atmosphere. Research studies indicate that weathering parameters influence strongly (67\%) compared to other factors like soil and nutrient management (33\%) during the cropping season. Researchers have confirmed that crop yield falls by 3-5\% for every $1^{\circ} \mathrm{F}$ increase in the temperature. Present study shows that the crop production is dependent on temperature and shows a funnel shape for all the seasons. At lower temperature both the properties are almost linearly correlated, whereas at higher temperatures, it increases but with large scattering. The findings may be helpful to study the effect of climate change on the crop production.
\end{abstract}

\section{Keywords}

global warming, climate change, Indian agriculture, crop yield

\section{Introduction}

Mankind is in need of an equitable standard of living like adequate food, water, energy, safe shelter and a healthy environment for present as well as future generations. But casual acts of human race, such as emission of greenhouse gases by burning fossil fuels and deforestation has increased the earth's average surface temperature, which is defined as global warming. It is proved that the warming on the earth's surface over last 50 years is mostly due to the anthropogenic activities (IPCC, 2007). Further, it is predicted that the global mean surface temperature will likely be in the range of $0.3-0.7^{\circ} \mathrm{C}$ for the period 2016-2035 (IPCC, 2014). This rise in temperature may cause various changes such as sea level rise, melting of snow sheets and change in rainfall pattern. Hence, global warming can be considered as the major affecting parameter in changing the earth's climate.

Warming of the climate system is observed all over the world. Recent climate changes have shown its impact on natural as well as human systems. Any significant change in climate may affect agriculture at larger scale. Various factors such as increase in temperature change in rainfall pattern, increase of $\mathrm{CO}_{2}$ 
content in atmosphere, frequency and intensity of extreme weather events may have significant impact in agriculture sector. It is predicted that increase in temperature will show overall negative effects on agriculture in the world (IPCC, 2001). Generally agricultural productivity in developing countries is expected to decline by $9-21 \%$ because of global warming (Cline, 2007). In case of India, almost $70 \%$ of the population depends on agriculture for their livelihood. 23\% of India's Gross National Product (GNP) representing agriculture sector alone, which plays a major role in the country's development and shall continue to hold an important place in the national economy (Khan et al., 2009). 2.4\% decrement in wheat yield was reported in China due to rising temperature over the past two decades (You et al., 2005). Increasing global mean surface temperature is very likely to lead changes in precipitation (Neenu et al., 2013). It is globally accepted that precipitation is a leading factor affecting especially rain fed crop yield (Izaurrale et al., 2003). Too much precipitation can cause disease infestation in crops, while too little can be detrimental to crop yields, especially dry periods occur during critical development stages (Neenu et al., 2013). Carbon dioxide is one of the significant parameter for plant growth. IPCC projected that atmospheric concentration of $\mathrm{CO}_{2}$ will increase from $368 \mu \mathrm{mol} / \mathrm{mol}$ to $540-970 \mu \mathrm{mol} / \mathrm{mol}$ in 2100 (IPCC, 2001). Research studies observed that a small increase in temperature $\left(2^{\circ} \mathrm{C}-40^{\circ} \mathrm{C}\right)$ had larger effect than elevated $\mathrm{CO}_{2}$ on grain quality (Tester et al., 1995; Williams et al., 1995). Rising trend of global warming is considered to be more striking than precipitation over the 20th century (Neenu et al., 2013).

\subsection{Global Scenario}

Climate change could be one of the affecting parameter all over the world. It is predicted by IPCC that many of the observed changes due to climate change are unprecedented (Huber et al., 2011). Global sea level rise is projected to be between 0.17-0.41 $\mathrm{m}$ in the year 2050 (Brown et al., 2015). It is observed that the rate of rising sea level has been larger than the mean rate during the previous two millennia, till the mid $19^{\text {th }}$ century (Kemp et al., 2011). IPCC reported that changes in precipitation will be non-uniform and its extreme events over most of the mid-latitude and wet tropical regions will become more intense and frequent (Kitoh et al., 2016). Recent finding of increasing trends in extreme precipitation leads to imply greater risks of flooding at regional scale (Kundzewicz et al., 2015). Since 1850 , last three decades has been consecutively warmer than any other decade on the Earth's surface. Heat wave frequency has increased since the middle of the $20^{\text {th }}$ century in large part of Asia (IPCC, 2014). Moreover concentration of $\mathrm{CO}_{2}$ and other greenhouse gases leads to increase the temperature. IPCC report states that the amount and rate of warming expected for the $21^{\text {st }}$ century depends on the total amount of greenhouse gases that mankind emit (National academics of sciences report, 2014). These observed changes are responsible for varying the climate at different parts of the Earth and sometimes it may result into extreme weather events.

In 2005, hurricane Katrina strike U.S., which is considered to be one of the most powerful storms in last 100 years. It struck the Gulf Coast region and reports estimated that the greatest farm production loss takes place due to this disaster. Prior to Katrina, in the same year, mid-west portions had 
experienced significant crop losses due to prolonged drought (Schnepf et al., 2005). Such climatic events affect the ecosystem worldwide. Climate change may increase or decrease the crop yield depending on the latitude of the area and irrigation application. Increasing temperature and varying precipitation may decrease the crop productivity in future (Kang et al., 2009). Temperature could be an impactful parameter which affects crop yield all over the world. Hence, studies related to effects of temperature on crop yield may help agriculture sector in a better way to plan and enhance the economy in the future.

\subsection{Indian Scenario}

Like other countries, India has also started experiencing extreme weather events which lead to change the climate. As mentioned earlier, global warming is one of the major affecting parameter to change the climate. In India, it is observed that the annual mean temperature has increased at the rate of $0.42^{\circ} \mathrm{C}$ (Arora et al., 2005). Indian agriculture system is based upon south-west and north-east monsoon. Almost $80 \%$ of the total precipitation comes from south-west monsoon in India. Any fluctuations and uncertainties in long range rainfall pattern may affect the agriculture sector and also lead to increase the frequency of droughts and floods at regional scale (Jain \& Kumar, 2012). A significant increasing trend in rainfall was reported along the west coast, north Andhra Pradesh and North West India (Jagannathan et al., 1973; Koteswaram et al., 1969), while significant decreasing trend was observed over parts of Gujarat, Madhya Pradesh and adjoining area, Kerala and northeast India (Krishnakumar et al., 2009). North western region of India gets affected by western disturbances at small scale as such disturbances have impact only on rabi production (Chand et al., 2015) only for not more than 20-30 days.

Not only monsoon, but temperature has also shown its effect on agriculture. Extreme maximum and minimum temperature showed an increasing trend in the southern part whereas decreasing trend in the northern part of India (Jain \& Kumar, 2012). Research studies show that with the increase in temperature, crop productivity is likely to decrease in future (Kang et al., 2009). Hence, there is a need to study the dependency of temperature on crop productivity, stability, yield and quality to uplift the country's economy.

\subsection{Effect of Increasing Temperature on Indian Agriculture}

Research studies shows that rise in global surface temperature would affect Indian agriculture. Several climatic factors which affect agriculture productivity are heat waves, high temperature (Ciais et al., 2005; Velde et al., 2012), heavy and prolonged precipitation (Pathak et al., 2011; Rosenzweig et al., 2002; Thakur et al., 2010) and excess cold. These factors have positive as well as negative effects on crop production. Almost every year India faces several weather events due to changes in such climatic parameters in various regions which reduces crop yield. Varied nature of such weather events tends to affect the crop growth cycle and plant physiological processes (Mahdi et al., 2015). In India, about 17\% of the years during 1901-2010 were reported as drought years, which result into severe impacts on agriculture, water resources, food security, economy and social life in the country (Niranjankumar et al., 2013). The variation in temperature and precipitation above threshold value may affect photosynthesis 
and transpiration process in crops (Porter et al., 2005). Excess rainfall and flood may leads to physical damage of the crops (Rosenzweig et al., 2002). Studies predicted that changing trends in temperature and precipitation will continue to have significant impact on agriculture (Neenu et al., 2013). A small rise in temperature $\left(1-2^{\circ} \mathrm{C}\right)$, especially in the seasonally dry tropical regions (IPCC, 2007) would decrease crop yield (Lakshmikumar et al., 2012).

In India, crop production may be divided into two seasons: kharif (influenced by south-west monsoon) and rabi (mostly influenced by north-east monsoon). It is reported that overall temperature rise is likely to be much higher during winter (rabi) rather than in rainy season (kharif) (Aggarwal et al., 2010). Moreover, it is predicted that the mean temperature in India will rise by $0.4-2.0^{\circ} \mathrm{C}$ in Kharif and $1.1-4.5^{\circ} \mathrm{C}$ in Rabi by 2070 (Khan et al., 2009). Decline in agricultural productivity leads to increase food prices at state as well as at country level (Udmale et al., 2014). Hence, temperature could be one of the significant affecting factor which results into greater instability in agriculture of India.

\section{Materials and Methods}

The data sets for the annual mean temperature of India over the period 1990-2013 was taken from India Meteorological Department (IMD). Development in the agriculture and allied sectors of India are of interest to a wide spectrum of people across the world. The Directorate of Economics and Statistics of the Department of Agriculture and Cooperation, Government of India publishes "Agricultural Statistics at a Glance 2014" that presents comprehensive information on this sector (Ministry of agriculture report, 2014). All the data sets of food grain production including rabi and kharif were taken from this report. The report contains production data from 1990-1991 to 2012-2013. In India, kharif crops are sown at the beginning of south-west monsoon (i.e., June to September) and harvested during autumn season (i.e., September to October). Such crops are highly dependent on the timings as well as amount of rainfall. Millets (Bajra, Jowar), Cotton, Soya bean, Sugarcane, Turmeric, Rice, Maize, Moong (Pulses), Groundnut, Red Chilies are several major Kharif crops in India. Rabi crops are sown after north-east monsoon (i.e., October to February) and harvested during spring season (i.e., February to April). The farmers in India are mainly dependent on this monsoon for growing the crops. Such crops need cool climate during growth period but warm climate during the germination of seed and maturation. Wheat, Barley, Gram, Linseed, Mustard, Masoor, Peas are several major Rabi crops in India.

\section{Result and Discussion}

\subsection{Trend of Temperature in India}

The annual mean temperature signifies an increasing trend with large fluctuations $\left(r^{2}=0.31\right)$, but with good statistical confirmation $(\mathrm{P}<0.05)$ over India (Figure 1$)$. The temperature is rising with overall rate of approximately $0.03^{\circ} \mathrm{C}$ per year from 1990 to 2013 . Over this period, high temperature $\left(25.29^{\circ} \mathrm{C}\right)$ and low temperature $\left(24.10^{\circ} \mathrm{C}\right)$ was observed during the year 1995-1996 and 1997-1998 respectively. 
In earlier decade (1990-2000), the overall temperature rise was about $0.5^{\circ} \mathrm{C}$ and in the later decade (2001-2013), it was about $1.45^{\circ} \mathrm{C}$, which denotes that current period is comparatively warmer than earlier decade. This long term temperature variation denotes the effect of global warming over India. High temperature may help some of the crops to grow faster, whereas some of them may get negatively affected (Aggarwal et al., 2010). Research confirms that every rise of $1^{\circ} \mathrm{C}$ temperature throughout the growing period, even after considering carbon fertilization will decline 4-5 million tons of wheat production in India (Aggarwal et al., 2010). Rice yield will decline by $10 \%$ for each $1^{\circ} \mathrm{C}$ increase in minimum temperature during the growing season (Peng et al., 2004). Hence an uneven pattern of temperature may affect crop yield as well as economy of the country.

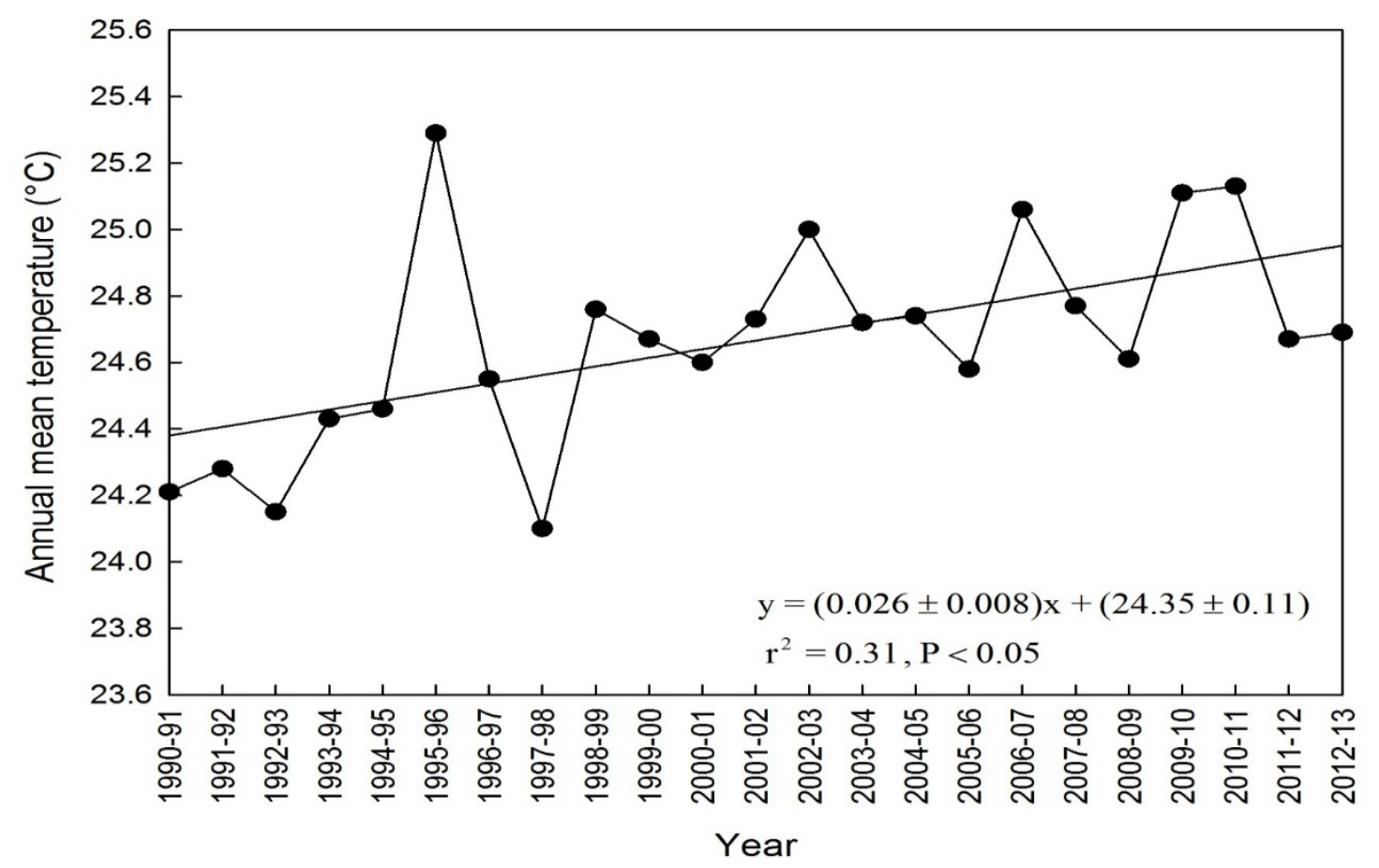

Figure 1. Annual Mean Surface Temperature Trend over India from 1990-2013

\subsection{Production of Overall Food Grains in India}

India is agriculture dependent country which produces varieties of food grains. The lines in the plots are drawn in such a way that almost all the points get cover within the structure. Hence, funnel like structure demonstrate the dependence of temperature on overall crop production in India (Figure 2).

Initially in low temperature range, tail portion show that crop production decreases with increase in temperature. After then, linear trend is observed which show that crop production increases with temperature. As temperature rises further, proportion of scattering increases. Thus, prediction at high temperature becomes difficult. This uneven pattern of temperature may affect crop yield in the country. Research study estimated that by 2020 , food grain requirement would be almost $30 \%-50 \%$ more than the current demand (Paroda et al., 2000). Hence, temperature could be one of the significant parameter Published by SCHOLINK INC. 
which helps to visualize the crop response.

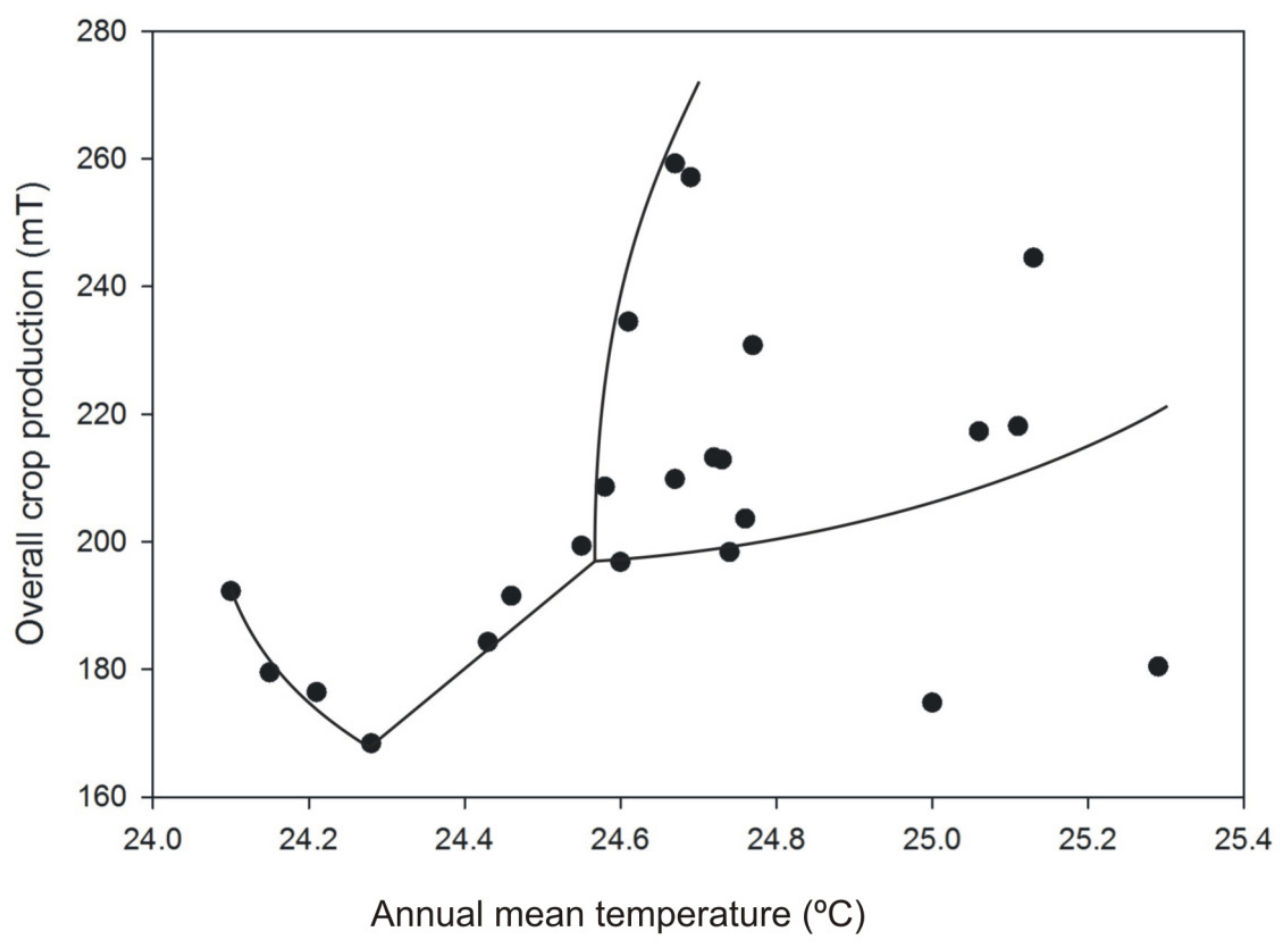

Figure 2. Variation of Overall Crop Production with Temperature

\subsection{Effect of Temperature Rise on Kharif Crops in India}

The dependency of temperature on kharif crops shows funnel like structure in Figure 3, which is as similar as in Figure 2. At initial stage, tail portion is not observed which signifies that kharif production may not get affected at low temperature. After that, at high temperature, scattering in the data points was observed. Hence, this makes the prediction difficult at high temperature range. The production for the year 1991-1992, 1995-1996, 2002-2003 and 2008-2009 has not been placed within the funnel like structure as during these years, several weather events took place in India.

During the year 1991-1992, production fell by 5.3\% compared to the previous year due to unpredictable behavior of south-west monsoon. Several depressions arose during the year 1995 which caused heavy to very heavy rainfall over Bihar plateau and Gangetic West Bengal. Such situation leads to flood and damage to crops was also reported (IMD, 1995). The year 2002 was declared as one of the severe drought in India (Mahdi et al., 2015). Due to this drought, production especially kharif crops got badly affected at large extent (Ministry of Finance, 1991-1992). Overall deficit of 23\% rainfall during the south west monsoon, in the year 2009-2010, adversely affected kharif production (Aggarwal et al., 2010). Hence due to such weather events, kharif production gets affected in India. 


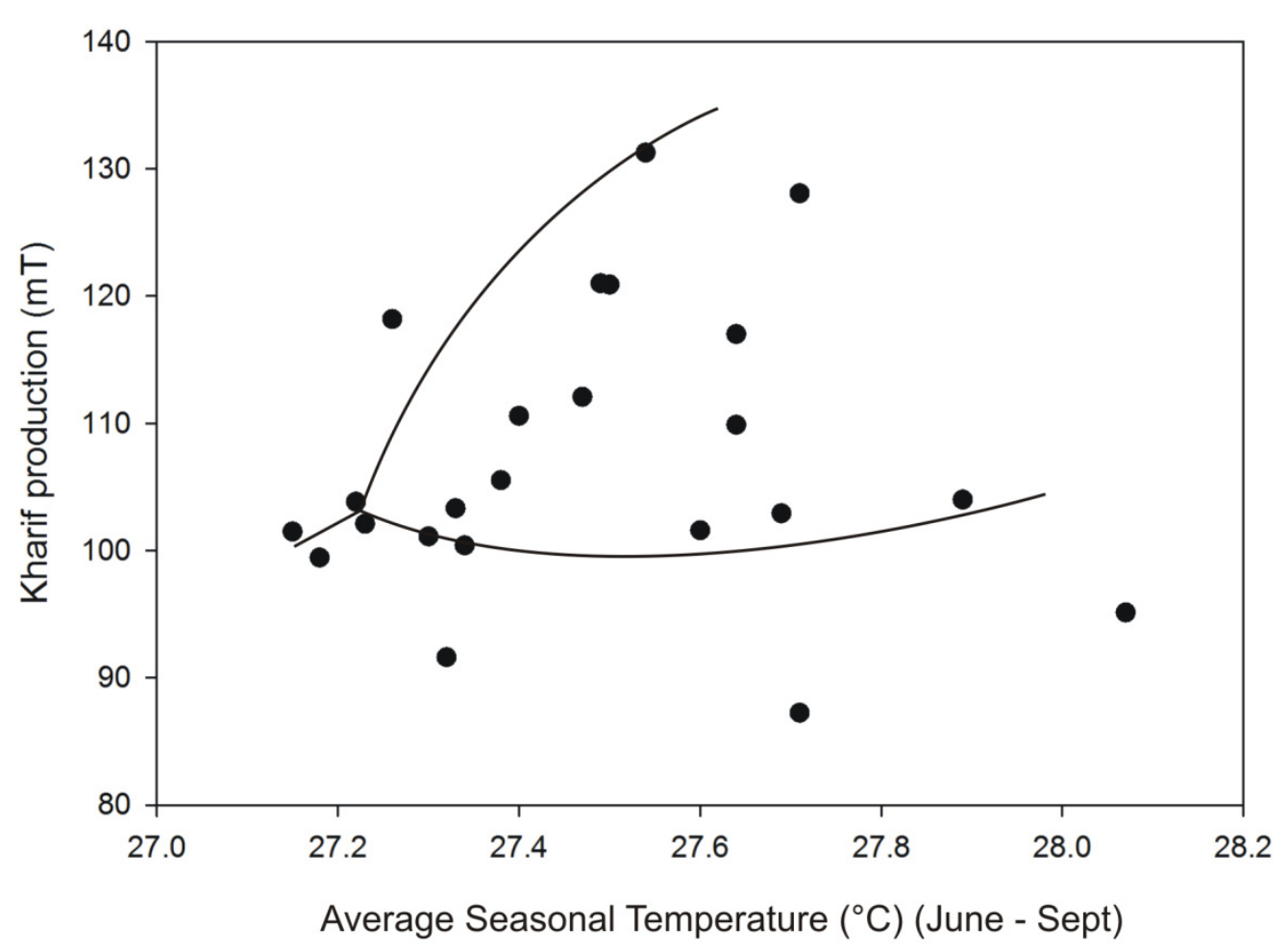

Figure 3. Variation of Kharif Production with Temperature

\subsection{Effect of Temperature Rise on Rice Production in India}

Rice is one of the major kharif crops in India. During north-east monsoon, almost two-third of total rice production takes place (Saravanakumar, 2015). Several other studies reported that increase in temperature beyond critical limits may contribute to reduce rice yield in future (Dash et al., 2007; Geethalakshmi et al., 2011). Thus variation in north-east monsoon and rise in temperature may have impact on rice production.

Rice production also show funnel like structure in Figure 4, which is same as shown in Figure 3. As mentioned earlier in Section 2.3, tail portion is not observed which signifies that rice production does not get affected at low temperature. It may also be possible that if we observe below this temperature range then we may get the tail portion. Same as kharif, increase in production takes place along with temperature rise but with high scatter. The reason for deviation in data points is already discussed in Section 2.3. 


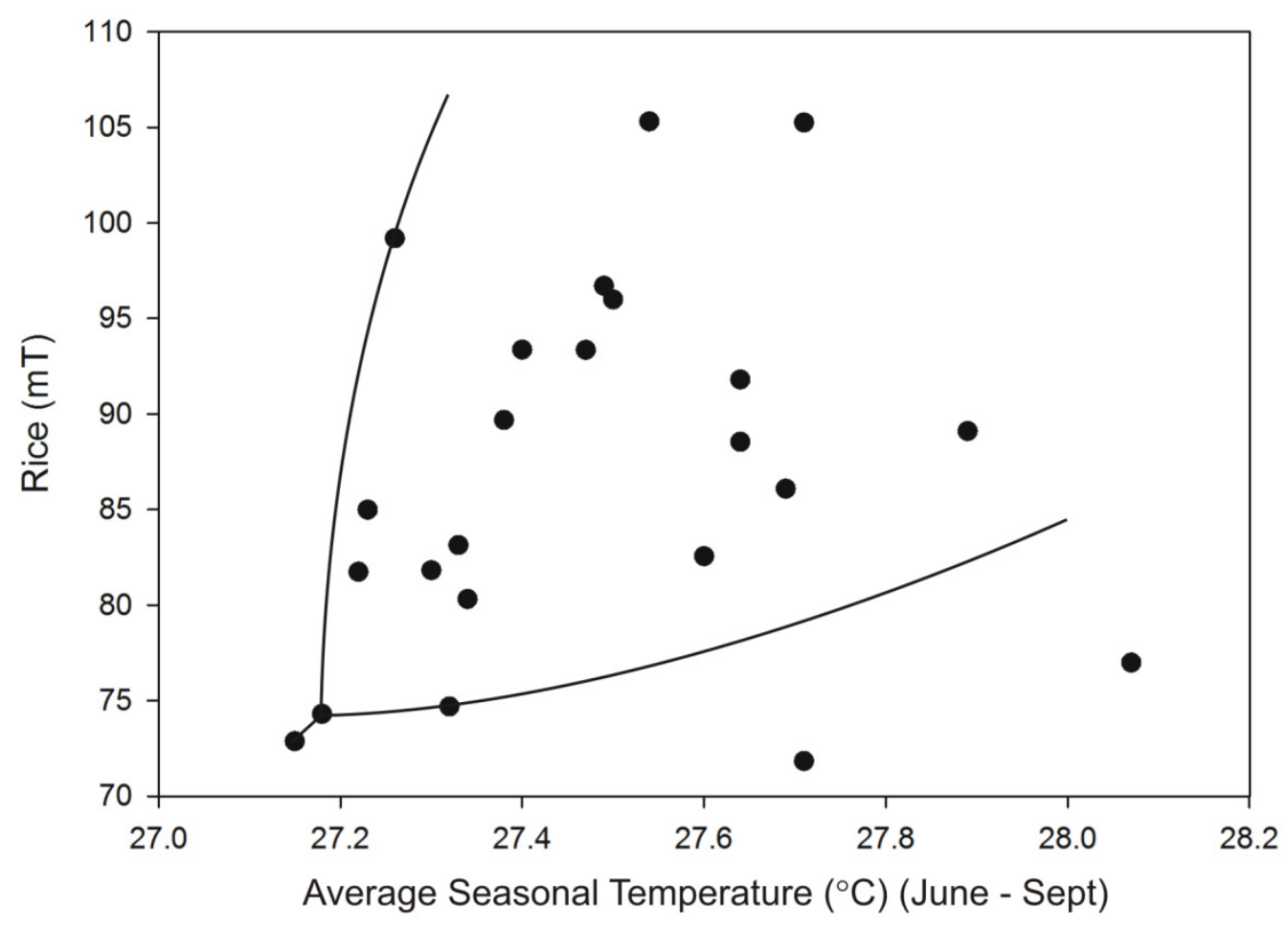

Figure 4. Variation of Rice Production with Temperature

\subsection{Effect of Temperature Rise on Rabi production in India}

Rabi production show funnel-like structure in Figure 5, which is similar as shown in Figure 3. Tail portion is observed which shows that rabi production gets affected at low temperature, which is same as Figure 2. After that rise in temperature shows linear relation with rabi production. Further rise in temperature shows high scattering. Same as for all, prediction becomes difficult at high temperature range. The production in the year 1995-1996 and 2006-2007 are not compiling within the funnel like structure due to extreme weather events took place in India.

During the year 1995, cyclonic storm at various places has reported loss of huge crop yield. Hence, overall rabi production in this year was affected (IMD, 1995). Moreover, the year 2007 was declared as flood year because series of floods hit India and hence production gets affected (Mahdi et al., 2015). 


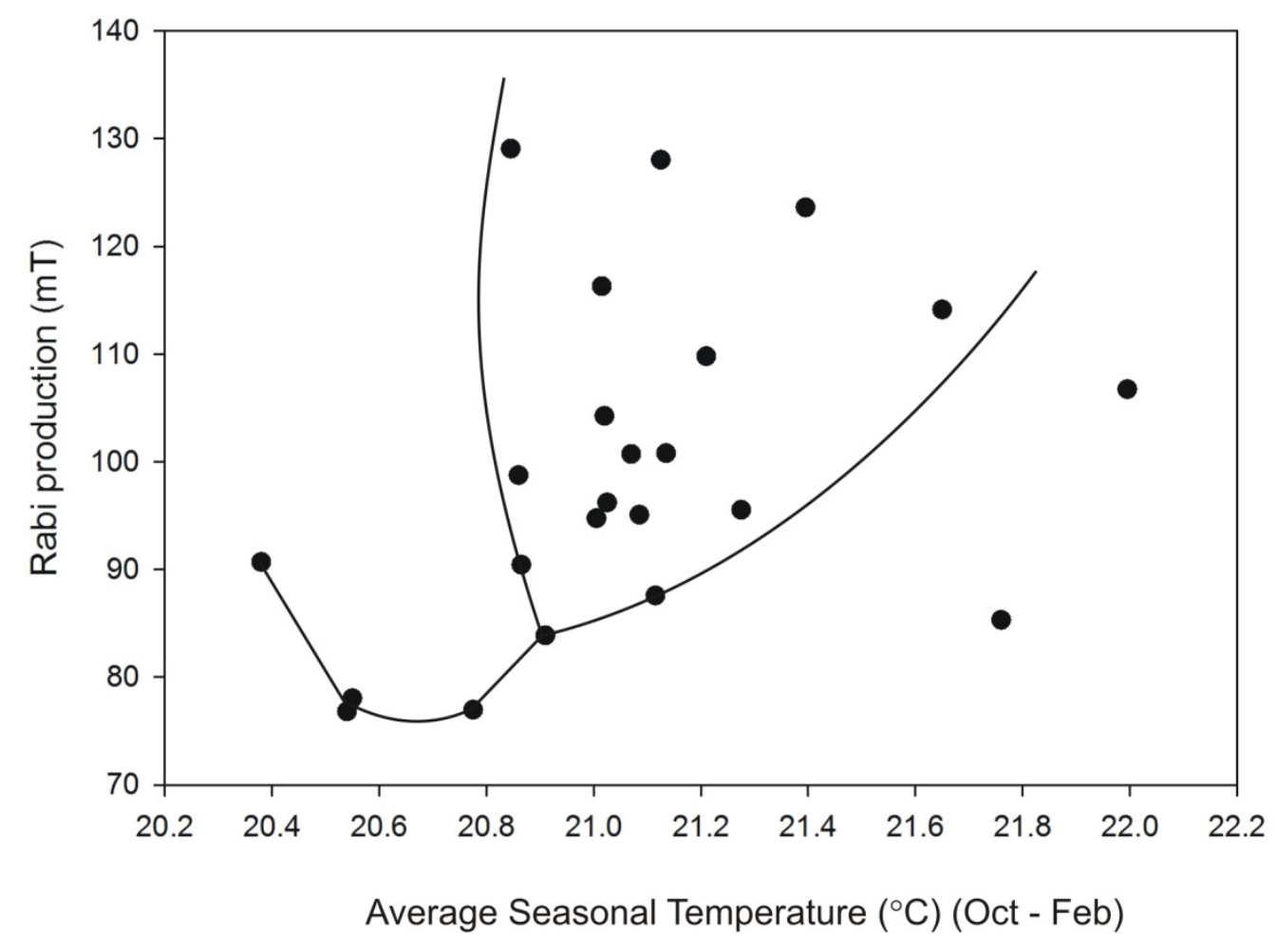

Figure 5. Variation of Rabi Production with Temperature

\subsection{Effect of Temperature Rise on Wheat Production in India}

Wheat is one of the major rabi crops in India. India is the second largest producer of wheat in the world after China. It is reported since past few years that the productivity of wheat is declining gradually even in Punjab and Haryana-the grainary of the Nation.

Wheat production also show funnel like structure in Figure 6, which is same as kharif production (Figure 5). At initial temperature range, production decreases with increase in temperature. Same as discussed earlier in Section 3.5 that scattering in wheat production is observed along with further rise in temperature. The reason for points which are deviating from funnel structure is already explained in Section 3.5. 


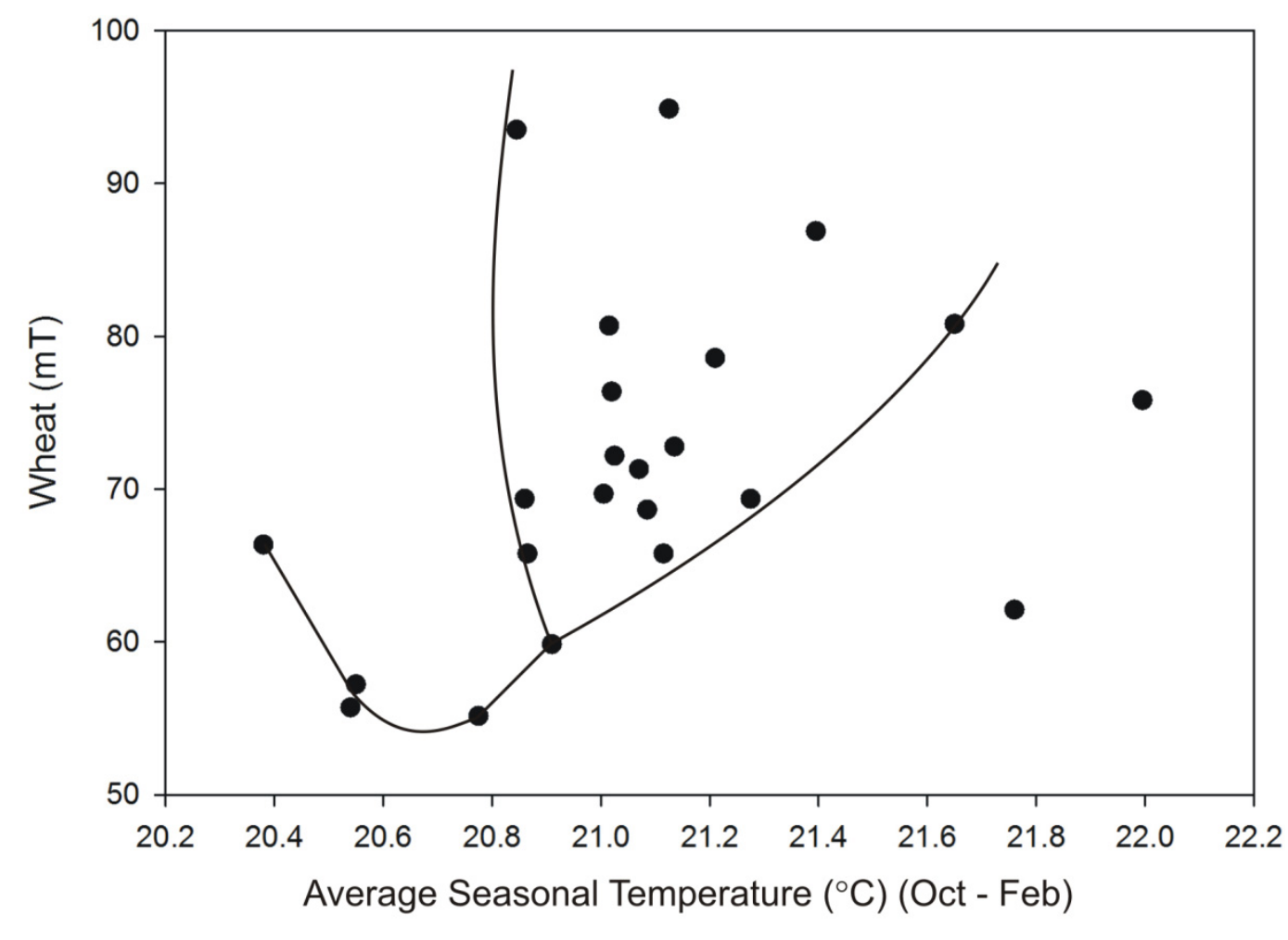

Figure 6. Variation of Wheat Production with Temperature

\section{Conclusion}

Present study shows that the crop production depends on temperature. Funnel-like structure is observed for overall production (including rabi and kharif) which signifies their dependency on temperature. At low temperature, tail portion was observed in rabi (wheat) production whereas not in kharif (rice). This shows that rabi production has affected comparatively more than kharif at lower temperature. At high temperature range, both types of production shows increasing trend. Moreover, in case of high temperature, it has been observed that scattering in production gets increases. Our study confirms the report of IPCC which states that crop production will get affected at high temperature. Hence, temperature can be one of the significant parameter in crop production studies. At high temperature, prediction of crop production may become difficult as the data points got more scatter. If anyhow, such predictions can be improved further then it may help farmers to make their field planning better, identification of appropriate crop type in particular field, estimation of crop yield and requirement of water for irrigation. In this way, damage to the crops can be minimized and better enhancement in the crop yield can be achieved. Hence, government needs to adopt such predictions and accordingly reframe their plans and policies which may help agriculture sector to uplift and hence can strengthen our economy. Predictions can be improved further by doing long term analysis as the present study contains data of only 23 years. Present study may be limited to the monsoon dominated region. Similar studies may be done for other regions as well to gain the confidence. 


\section{References}

Aggarwal, P. K., Kumar, S. N., \& Pathak, H. (2010). Impacts of climate change on growth and yield of rice and wheat in the Upper Ganga Basin. Indian Agricultural Research Institute (IARI).

Arora, M., Goel, N. K., \& Singh, P. (2005). Evaluation of temperature trends over India. Hydrological Sciences and Water Security: Past, Present and Future, 50(1).

Brown, S., Lincke, D., Nicholls, R. J., \& Hinkel, J. (2015). The impacts of sea-level rise on European coasts in a $2^{\circ} \mathrm{C}$ world.

Chand, R., \& Singh, C. (2015). Movements of western disturbance and associated cloud convection. Journal of Indian Geophysical Union, 19(1), 62-70.

Ciais, P. et al. (2005). Europewide reduction in primary productivity caused by the heat and drought in 2003. Nature, 437(7058), 529-533. https://doi.org/10.1038/nature03972

Cline, W. (2007). Global warming and agriculture: Impact estimates by country. Centre for Global Development.

Dash, S. K., \& Hunt, J. C. R. (2007). Variability of climate change in India. Current Science, 93(6).

Geethalakshmi, V. et al. (2011). Climate change impact assessment and adaptation strategies to sustain rice production in Cauvery basin of Tamil Nadu. Current Science, 101.

Huber, D. G., \& Gulledge, J. (2011). Extreme Weather and Climate change: Understanding the link and managing the risk. Center for Climate and Energy Solutions.

IMD. (1995). Report on cyclonic disturbances over North Indian Ocean during 1995.

IPCC. (2001). Climate Change: Synthesis Report 2001. Wembley, United Kingdom.

IPCC. (2007). Climate Change 2007: Impacts, Adaptation and Vulnerability. Cambridge University Press, Cambridge, UK.

IPCC. (2014). Climate Change 2014: Synthesis Report. IPCC, Geneva, Switzerland.

Izaurrale, R. C., Rosenberg, N. J., \& Brown, R. A. (2003). Integrated assessment of Hardley Center (HadCM2) climate change impacts on agricultural productivity and irrigation water supply in the conterminous United States Part II. Regional agricultural production in 2030 and 2095. Agriculture and Forest Meterology, 117, 97-122.

Jagannathan, P., \& Parthasarathy, B. (1973). Trends and Periodicities of Rainfall over India, 101(4).

Jain, S. K., \& Kumar, V. (2012). Trend analysis of rainfall and temperature data for India. Current Science, 102(1).

Kang, Y., Khan, S., \& Ma, X. (2009). Climate change impacts on crop yield, crop water productivity and food security-A review. Progress in Natural Science, 19(12), 1665-1674. https://doi.org/10.1016/j.pnsc.2009.08.001

Kemp, A. C. et al. (2011). Climate related sea-level variations over the past two millennia. Proceedings of the National Academy of Sciences, 108(27). https://doi.org/10.1073/pnas.1015619108

Khan, S. A., Kumar, S., Hussain, M. Z., \& Kalra, N. (2009). Climate Change, Climate Variability and Indian Agriculture: Impacts Vulnerability and Adaptation Strategies. In R. Allan, U. Forstner, \& W. 
Salomons (Eds.), Climate Change and Crops: Springer.

Kitoh, A., \& Endo, H. (2016). Changes in precipitation extremes projected by a $20-\mathrm{km}$ mesh global atmospheric model. Weather and Climate Extremes, 11, 41-52. https://doi.org/10.1016/j.wace.2015.09.001

Koteswaram, P., \& Alvi, S. M. A. (1969). Trends and periodicities in rainfall at west coast stations in India. Current Science, 38(10), 229-231.

Krishnakumar, K. N., Rao, G. S. L. H. V. P., \& Gopakumar, C. S. (2009). Rainfall trends in twentieth century over Kerala, India. Atmospheric Environment, 43, 1940-1944. https://doi.org/10.1016/j.atmosenv.2008.12.053

Kundzewicz, Z. W., \& Matczak, P. (2015). Hydrological extremes and security. Hydrological Sciences and Water Security: Past, Present and Future.

Lakshmikumar, T. V., Barbosa, H., Rao, K. K., \& Jothi, E. P. (2012). Some Studies on the Frequency of Extreme Weather Events over India. Journal of Agricultural Science and Technology, 14(6), 1343-1356.

Mahdi, S. S., Dhekale, B. S., Choudhury, S. R., Bangroo, S. A., \& Gupta, S. K. (2015). On the climate risks in crop production and management in India. Australian Journal of Crop Science, 9(7), 585-595.

Ministry of Finance, Government of India. (1991). The Economy in 1991-92: Performance and Prospects.

Neenu, S., Biswas, A. K., \& Rao, A. S. (2013). Impact of climatic factors on crop production-A review. Agriculture reviews, 34(2), 97-106.

Niranjankumar, K., Rajeevan, M., Pai, D. S., Srivastava, A. K., \& Preethi, B. (2013). On the observed variability of monsoon droughts over India Weather and Climate Extremes, 1, 42-50.

Paroda, R. S., \& Praduman, K. (2000). Food production and demand in South Asia. Agricultural Economics Research Review, 13(1), 1-24.

Pathak, H., Byjesh, K., Chakrabarti, B., \& Aggarwal, P. K. (2011). Potential and cost of carbon sequestration in Indian agriculture: Estimates from long term field experiments. Field Crops Research, 120(1), 102-111. https://doi.org/10.1016/j.fcr.2010.09.006

Peng, S. et al. (2004, June 28). Rice yields decline with higher night temperature from global warming. Paper presented at the Proceedings of the National Academy of Sciences of the United States of America, USA. https://doi.org/10.1073/pnas.0403720101

Porter, J. R., \& Semenov, M. A. (2005). Crop responses to climatic variation (Vol. 360, No. 1463, pp. 2012-2035). The Royal Society Publishing. https://doi.org/10.1098/rstb.2005.1752

Rosenzweig, C., Tubiello, F. N., Goldberg, R., Mills, E., \& Bloomfield, J. (2002). Increased crop damage in the U.S. from excess precipitation under climate change. Global Environment Change. https://doi.org/10.1016/S0959-3780(02)00008-0

Saravanakumar, V. (2015). Impact of Climate Change on Yield of Major Food Crops in TamilNadu. 
India. https://doi.org/10.1016/S0733-5210(05)80008-6

Schnepf, R., \& Chite, R. M. (2005). U.S. Agriculture after Hurricane Katrina: Status and Issues.

Tester, R. F. et al. (1995). Effects of elevated growth temperature and carbon dioxide levels on some physicochemical properties of wheat starch. Journal of Cereal Sciences, 22(1), 63-71.

Thakur, P., Kumar, S., Malik, J. A., Berger, J. D., \& Nayyar, H. (2010). Cold stress effects on reproductive development in grain crops: An overview. Environmental and Experimental Botany, 67, 429-443. https://doi.org/10.1016/j.envexpbot.2009.09.004

The Directorate of Economic and Statistics in the Ministry of Agriculture, Government of India. (2014). Agricultural Statistics at a Glance 2014.

The Royal Society, National Academics of Sciences. (2014). Climate Change: Evidence and Causes: An overview from the Royal Society and the US National Academy of Sciences.

Udmale, P. D., Ichikawa, Y., Kiem, A. S., \& Panda, S. N. (2014). Drought Impacts and Adaptation Strategies for Agriculture and Rural Livelihood in the Maharashtra State of India. The Open Agriculture Journal, 8, 41-47. https://doi.org/10.2174/1874331501408010041

Velde, M. V. D., Tubiello, F. N., Vrieling, A., \& Bouraoui, F. (2012). Impacts of extreme weather on wheat and maize in France: Evaluating regional crop simulations against observed data. Climatic Change, 113(3), 751-765. https://doi.org/10.1007/s10584-011-0368-2

Williams, M., Shewry, P. R., Lawlor, D. W., \& Harwood, J. L. (1995). The effects of elevated temperature and atmospheric carbon dioxide concentration on the quality of grain lipids in wheat (Triticum aestivum L.) grown at two levels of nitrogen application. Plant Cell Environment, 18, 999-1009. https://doi.org/10.1111/j.1365-3040.1995.tb00610.x

You, L., Mark, R. W., Fang, C., \& Wood, S. (2005). Impact of global warming on Chinese wheat productivity. EPTD discussion papers. International Food Policy Research Institute (IFPRI), 143. 